\title{
КОЛЛЕКТИВИЗАЦИЯ ПОТРЕБЛЕНИЯ КАК МЕРА ПРОТИВОДЕЙСТВИЯ РАСПРОСТРАНЕНИЮ ВИРУСНОЙ ИНФЕКЦИИ
}

Проблема распространения коронавирусной инфекции заставляет поновому взглянуть на организацию экономики. Как сохранять жизнеспособность народного хозяйства при условии резкого сокращения личных контактов людей во избежание передачи заболевания в условиях пандемии? Как обеспечивать новую инвестиционную активность? Как повысить дисциплину, связанную с реализацией мер противодействия эпидемиям?

Если в организациях, имеющих иерархическую систему управления, можно заставить их членов выполнять правила, то за пределами рабочих мест на людей сложно влиять без применения полицейских мер. В магазинах и общественном транспорте постоянно возникают скопления случайных людей, без соблюдения санитарных правил порождающие неконтролируемое распространение инфекции.

В связи с этим предлагается ввести систему управления потреблением, ограничив магазинную розничную торговлю и развив кооперацию потребителей. $B$ основе предлагаемых изменений лежит новый механизм отношений граждан, власти и некоммерческих организаций, т. е. более развитая система их социального партнерства, чем сегодня.

В результате преобразования системы снабжения местных жителей региональная власть сможет влиять на характер потребления через участие в постановке задач поставщикам совместно с гражданами. Таким образом, опираясь на интересы населения, она сможет качественнее определять направление инвестирования средств бизнеса в развитие производства товаров и осуществления услуг.

Соблюдение местных правил потребления и общежития, разрабатываемых органами самоуправления и принимаемых гражданами решениями общих собраний, обеспечит повышение качества потребления, снижение необходимости в полицейских мерах для сохранения правопорядка (в том числе, при реализации карантинных мероприятий), а также создаст дополнительную инвестиционную активность посредством системы группового формирования спроса на новые товары и изменения экономического статуса ритейла.

Карантин, самоизоляция, потребительская кооперация, самоуправление, социальное партнерство, совместные покупки, розничная торговля, городской транспорт. 


\section{ВВЕДЕНИЕ}

Сегодня мир столкнулся с новой вирусной угрозой, и большинство стран предприняло карантинные меры, при этом они были вынуждены разорвать многие экономические связи - как внутренние, так и международные. Это вызвало серьезные проблемы в экономике, причем далеко не всем странам созданные ограничения обеспечили возможность локализовать распространение инфекции до нулевого уровня, а значит, нужны дополнительные или иные меры.

Доступные сегодня методы карантинной самоизоляции граждан, предназначенные для остановки или хотя бы ограничения распространения коронавирусной инфекции, оставляют необходимость контактирования случайных по отношению друг к другу людей. Это в первую очередь относится к посещению магазинов, и пользованию общественным транспортом. В действующих организациях не так сложно отследить контакты людей и локализовать очаги распространения инфекции, как в общественных местах.

Поэтому цель исследования - предложить эффективные организационные меры карантинной самоизоляции направленные на ограничение возможностей встречи незнакомых между собой людей и при этом добиться роста инвестиционной активности.

Выдвигаемая рабочая гипотеза заключается в следующем: осуществление покупок через потребительскую кооперацию сократит число физических контактов между случайными людьми, а, следовательно, предотвратит возможность хаотичного распространения инфекции.

Российские источники, посвященные реализации противоэпидемических мер, можно разделить на четыре основные группы освещения проблематики.

1. Анализ правомерности решений власти с точки зрения законодательства [1-2]. Рассматривается соответствие принятых законов и постановлений Конституции Российской Федерации. Авторы анализируют имеющиеся противоречия в законодательстве и предлагают свои пути их преодоления.

Следует отметить, что ограничения магазинной торговли тоже могут вызвать сомнения и возражения с правовой точки зрения и потребовать изменения законодательства. Однако с позиции права граждан на жизнь и здоровье правомерны любые действия, вызывающие какие-либо неудобства, новые издержки и дополнительные усложнения общественной системы.

То, как предлагаемые ограничительные меры сочетаются с действующим законодательством, в данной работе не рассматривается, в ней преследуется цель обосновать хозяйственную целесообразность закрытия магазинов для их частного посещения гражданами и преобразования общественного транспорта как во время пандемии, так и после нее.

Также в данной статье не проводится экономический анализ необходимых издержек для обоснования экономической целесообразности предлагаемых мер, так как не существует приемлемых методик материальной оценки ценности человеческих жизней. При этом очевидно, что даже эпидемии простудных 
заболеваний наносят ежегодно значительный ущерб людям и экономике, не говоря уже о риске возникновения новых, более опасных, вирусов, чем COVID-19.

2. Новые логистические решения, связанные с использованием автоматов по продаже товаров, увеличением объема доставки товаров на дом и развитием Интернет-торговли [3-4]. Очевидно, что это направление конкурирует с методом, предлагаемым в данной статье. Однако его следует отнести к рудиментарной ветке развития торговли, нацеленной на техническую сторону улучшения выдачи товаров. Данное направление лишь заостряет проблему удовлетворения интересов потребителей, так как удлиняет обратную связь между потребителями и поставщиками. Кооперация же, напротив, призвана усилить взаимодействие потребителей и производителей.

3. Вопросы вынужденного одиночества с психологической и философской точек зрения [5-7], в том числе связанные с природой неготовности людей самоизолироваться. Предлагаемое групповое ограничение коммуникаций предусматривает усиление изоляции сообществ, но не отдельных людей, при котором проблемы одиночества не должно возникать. Источником одиночества является наблюдаемая сегодня индивидуализация жизни, а кооперация делает людей взаимозависимыми, а, значит, не одинокими. Это дает основание рассчитывать на более высокий уровень выполнения противоэпидемических мер.

4. Большое количество статей посвящено описанию финансового кризиса, вызванного разрывом экономических связей из-за принимаемых противоэпидемических мер [8-9]. Очевидно, что кооперативный подход к изменению торговли не ограничивает поставки товаров, а, наоборот, направлен на создание новых экономических связей.

Следует отметить, что тематика развития потребительской кооперации в качестве противоэпидемической меры в современной научной литературе не освещается.

\section{Логика преобразования магазина в логистический центр}

Очевидно, что для многих людей, которые стремятся выдержать режим самоизоляции, единственным местом, где они неизбежно подвергаются угрозе заражения, являются магазины.

Для магазина выполнение усиленных санитарных требований предполагает дополнительные издержки. В них входят расходы на мощную вентиляцию помещений, усиленные меры санитарной обработки, использование масок и прочих индивидуальных средств защиты для сотрудников, организация потока посетителей магазина, обеспечение социальной дистанции и прочие меры. Для предприятий торговли требование строгого соблюдения гигиенических мер покупателями означает уменьшение их числа до тех пор, пока в обществе карантинные скептики не останутся в меньшинстве. Поэтому усиленные санитарные нормы без внешнего принуждения магазинов и их посетителей в большинстве случаев не выполняются.

Такие личностные факторы, как психологическая защита (отрицание, непризнание существования реальной проблемы), низкий уровень солидарности 
граждан, правовой нигилизм, коррупция, невысокий уровень образованности для эффективной защиты от инфекции себя и окружающих граждан, играют отрицательную роль в реализации полноценной самоизоляции населения. Это делает невозможным эффективное подавление передачи инфекции как на ранней стадии возникновения, так и по мере ее распространения.

Таким образом, принимаемые сегодня ограничительные меры не смогут обеспечить условия для стопроцентного подавления распространения вирусной инфекции.

В связи с этим целесообразно закрыть все магазины как распространители инфекции для посещения розничными покупателями, организовав совместные кооперативные закупки для жильцов многоквартирных домов (МКД) и домов по соседству.

Речь не идет о замещении бизнеса потребительскими и производственными кооперативами по Р. Оуэну и Ш. Фурье. Предлагается развитие социального партнерства между бизнесом, гражданами и государством [10] с повышением значимости интересов потребителей при формировании общественных программ развития.

Данный кооперативный способ реализации товаров не приведет к потере рабочих мест сотрудниками торговли, функции которых несколько изменятся. Магазин в этом случае превращается в логистический центр, а сотрудник магазина осуществляет размещение товаров в потребительскую корзину (посылку). Далее совокупность посылок, предназначенных потребителям, должна быть доставлена им бесконтактным способом.

Это кардинально снизит риск одновременного заражения большого числа людей, позволит лучше отследить цепочки заражения, если таковое произошло.

Организаторам совместных покупок легче их реализовать, если не менять прежних поставщиков, работая с привычными для покупателей магазинами. Объем сбыта для магазинов не должен радикально измениться на первых порах. Инертность потребителей обеспечит преемственность торговых отношений при их дальнейшем преобразовании в изменившихся условиях.

Помимо повышенного риска заражения граждан коронавирусом (и прочей инфекцией) супермаркеты и иные магазины имеют множество других недостатков, которые можно решить с помощью кооперации потребителей.

При этом если применять прежние подходы к потребительской кооперации, не выдержавшие конкуренции, то выполненные преобразования экономических отношений по окончании эпидемии будут отторгнуты обществом. Так как вирусная угроза навсегда не исчезнет из-за достаточно быстрого процесса эволюции микроорганизмов, необходимо довести массовый дистанционный способ покупок до более конкурентоспособного состояния.

\section{Недостатки современной кооперации}

Основной мотив современных совместных покупок с момента появления первых эффективных потребительских кооперативов - это экономия денежных 
средств на большом объеме покупок, совершаемых сообща по оптовым ценам с меньшей наценкой, чем в розничной торговле.

Массовое кооперативное снабжение возникло в середине 20-го века, оно потеснило розничных продавцов, но далее его заместила система супермаркетов, которые, входя в состав кооперативов, наравне с рядовыми членами участвовали в совместной закупке по оптовым ценам. Это дало им возможность обеспечить для конечного потребителя цены, сопоставимые с кооперативными.

Сегодня крупные торговые сети превосходят по оптовым объемам любой вновь появившийся кооператив или легко смогут его превзойти, как только тот начнет расширяться.

Получение товара в кооперативном секторе предполагает дополнительную работу. Членам кооперативов нужно участвовать в собраниях, в коллективном хозяйстве, т. е. брать на себя дополнительную ответственность. Совершение покупки в кооперативе заключается в получении предоплаченного товара, что исключает борьбу продавца за покупателя на этапе поставки. Из-за этого страдает качество обслуживания.

Этих неудобств лишен супермаркет. К тому же граждане получили больше возможностей одним походом в магазин удовлетворить максимально широкий набор своих потребностей.

При этом реализация совместных покупок (после длительного спада потребительской кооперации) получила новый импульс благодаря специализированным сайтам в сети Интернет. Здесь, в отличие от кооперативов, создание групп потребителей с общими интересами происходит стихийно, после покупки они, как правило, распадаются.

Данный способ торговли сразу продемонстрировал свои недостатки, в частности, неопределенность статуса организатора совместной покупки [11-12]. Он является продавцом товаров или организатором сбора людей на их совместное приобретение? Организатору покупки выгодно быть аффилированным поставщиками агентом, а перед потребителями позиционироваться организатором сбора людей и распространения совместно приобретенного.

Из-за нечеткой отчетности организатора за совместную покупку сделка совершается с неоднозначным для пользователя результатом. На сайте совместных покупок потребитель может получить товар, отличающийся от заказанного по размеру, цвету, цене (из-за того, что заранее невозможно оценить все издержки). Далее потребитель вынужден решать, как с полученным товаром обращаться - «пристраивать» его (обычно на том же Интернет-ресурсе) или оставить себе.

Также неэффективно проявила себя потребительская кооперация совладельцев многоквартирных домов (МКД). Собственники не имеют существенного влияния на расходование собираемых денежных средств УК и ТСЖ, которые, как правило, не формируют систему учета интересов жильцов [13], несмотря на то, что данные юридические лица при продаже своих услуг собственникам МКД тоже позиционируются как организаторы общего потребления ресурсов. Фактически, УК и ТСЖ диктуют свою волю потребителям. 
Собрав принудительно (по действующему законодательству) квартплату, им выгоднее быть агентами поставщиков услуг (в том числе выполнять работу своими силами), чем организовывать удовлетворение интересов собрания собственников перед поставщиками услуг.

Такая система взаимоотношений совладельцев МКД с УК и ТСЖ тоже требует изменения принципов организации совместной покупки собственниками работ по содержанию и ремонту МКД, а также прочих услуг.

Поэтому кооперации (совместным покупкам), помимо экономии средств покупателей, следует акцентироваться на своем дополнительном назначении - на организованном выдвижении потребительских требований поставщикам. Для этого целесообразно выделить принятие решения общим собранием потребительского общества в отдельную систему, которая будет определять волю участников, с одной стороны, и являться инструментом формирования организованного спроса, с другой. Подчиненный этой воле агент (кооператив) должен выполнять задание покупателей, заключив соответствующие договоры с поставщиками товаров и услуг.

\section{Недостатки магазинной торговли}

Функции потребкооперации как «профсоюза» потребителей и постановщика задач для производителей определяются системными недостатками магазинной торговли. Ниже перечислены основные из них.

1. Чтобы завлечь покупателей, магазину нужно всегда иметь необходимый объем товаров, на которых он специализируется [14]. Это означает, что товары должны иметь большой срок годности - как физической, так и моральной. Когда он проходит, товары необходимо утилизировать. Это дополнительные издержки для продавца и, в итоге, потребителя, а также избыточное природопользование, так как для данного способа торговли производится заведомо больший объем товаров, чем может использоваться людьми. Кооперативный предзаказ не имеет такого недостатка.

2. Широкий ассортимент товаров имеет большое значение для привлечения покупателя в магазин [15]. В итоге не все товары будут куплены, часть из них придется утилизировать. Покупка по техническому заданию решает данную проблему. Достижение консенсуса в потребительской группе обеспечит возможность серийности производства.

Чтобы победить в конкурентной борьбе при кооперативном сбыте, необходим не запас товаров на складе, а избыток производственных мощностей и технологической гибкости для более быстрой адаптации к изменениям спроса. Наличие предоплаты на расчетном счете кооператива, подтверждающей готовность покупателя совершить покупку, обеспечит новую инвестиционную активность в реальном секторе экономики.

3. Приемы современного маркетинга побуждают потребителей в магазине делать эмоциональные, рефлексивные покупки, обусловленные личными качествами продавца, красивой упаковкой и прочими иррациональными 
составляющими. Таким образом, мы, по сути, делаем ненужные нам приобретения.

Покупка по предзаказу, обсужденная с подобными участниками группы совместной покупки, делает требования к приобретаемым товарам более рациональными. Упаковка утрачивает прежнюю функцию привлечения покупателей и может быть упрощена, что положительно скажется на цене товара и объеме производимого мусора. Потребности фиксируются техническим заданием - лишенным эмоций документом. Это обеспечит более высокие темпы товарного развития и вслед за ним - научно-технического прогресса.

Предзаказ требует планирования личного потребления. Это также снижает личные издержки на покупку ненужного. Однако планирование покупок - это работа, от которой нас избавляет спонтанное удовлетворение потребностей посредством получения товара с полки магазина.

Именно это в сочетании с другой сложной работой по согласованию интересов людей, а также необходимостью изменения своих привычек, следует отнести к основным причинам, почему более эффективная в экономическом плане система кооперативного потребления не может возникнуть сама собой посредством прямой конкуренции с магазинами. Для ее внедрения необходимо признать покупку такой же работой, как и создание товаров, и реформировать под эту систему большую часть экономики, выделив на осуществление предзаказа рабочее время. За это время потребкооперация должна сформировать задание производству на ближайший период и обозначить долгосрочные планы. Лучше меньше производить, но делать более полезные товары.

Обсуждение интересов широкого числа потребителей за столом переговоров в группе (а во время самоизоляции - с помощью телекоммуникационных средств) позволит избежать многих скрытых проблем, которые не в состоянии увидеть разработчик. Таким образом, конструкторская деятельность отчасти перемещается с завода в потребительский кооператив для осуществления предпроектной проработки будущих товаров.

Сложная работа по согласованию технических заданий возможна в перспективе, а сегодня можно обойтись простой покупкой тех же самых обыденных товаров, что есть на прилавках магазинов, без дискуссий и сложных систем принятия коллективных решений. Далее на почве возникающих противоречий придется все более и более усложнять систему кооперации.

Очевидно, что это идеальная модель. Полностью организовать потребление по предзаказу очень сложно, но эти отношения можно сделать доминирующими над магазинным способом приобретения товаров. Сегодняшнее разрушение экономических связей с остановкой прежнего производства, вызванной карантинными мерами, с одной стороны, потребует новых приемов ее оживления, а с другой, обеспечит благоприятные условия для реализации кооперативной формы хозяйственных отношений с запуском совершенно новых, гораздо более перспективных, проектов.

4. Высокий уровень монополизации торговли создает проблемы для потребителей, связанные с монопольным извлечением прибыли, ограничением 
возможности выбора и пр. В противовес бизнесу потребительская кооперация способна создать монопольное потребление. Кооперативы, объединившись в союзы, приобретают очень крупный масштаб, в том числе международный.

Целесообразно наделить потребкооперацию функцией инструмента формирования заявок на объем производства, создания технических требований и определения цен товаров при непосредственном сборе технических и экономических сведений (требований) от потребителей.

Речь идет о преобразовании государственного управления бизнесом в общественное кооперативное с заменой метода влияния государственной власти не на производство, а на характер и объем потребления [16].

В этом методе реализации управленческих отношений потребитель при поддержке власти влияет на бизнес, а не власть, опираясь на мнение потребителей, управляет бизнесом напрямую. Таким образом можно достичь более высокого качества самого производства, так как оно будет определяться в большей степени аффилированными представителями потребителя, находящимися в проблемной ситуации, а не чиновниками, являющимися сторонними наблюдателями [17].

5. Качество продукции на полках магазинов проверяется в настоящее время не подотчетными потребителям организациями. Они не находятся в проблемной ситуации потребителя, поэтому недостаточно эффективны в плане удовлетворения потребительских интересов [18]. То же можно сказать про государственный контроль соблюдения карантинных мер.

Чтобы интересы покупателей соблюдались, необходимо либо насильственное принуждение со стороны власти, либо влияние потребителей на поставщика. Без применения силы власти осуществление влияния возможно только со стороны крупного покупателя, каковым является потребительская кооперация.

6. Помимо повышения качества потребления кооперация приведет к положительным социальным изменениям. Чтобы достичь консенсуса, нужны позитивные межличностные отношения. Они диктуются экономической необходимостью данной формы хозяйствования.

Это значит, что организаторы и рядовые члены кооперации заинтересованы в развитии у людей навыков разрешения конфликтов, в повышении уровня культуры участников, подталкивающих к позитиву по отношению друг к другу [19]. В итоге, можно рассчитывать на улучшение статистики по объему и тяжести преступлений в обществе.

\section{Развитие отношений кооперации потребителей с торговыми сетями}

Из вышеперечисленного следует, что закрытие магазинов на карантин с массовым переводом общества на кооперативное потребление является не временной мерой, а вложением усилий в формирование новой экономики. После карантина возможен частичный или полный возврат к прежнему способу 
снабжения, но более перспективным является совместное кооперативное потребление граждан.

Форма бизнеса торговых сетей должна измениться.

Перестав быть главным посредником между конечным покупателем и производителем, ритейлеры утратят возможность диктовать свои условия поставщикам в прежнем виде. Производитель предпочтет, по возможности, работать напрямую с потребительскими кооперативами. Формируя большой заказ, потребительская кооперация тоже заинтересована свести посреднические издержки к минимуму.

Однако, бывшие ритейлеры могут не только продавать свои услуги логистики, но и зарабатывать инвестициями в производство товаров, которые поставляют кооперативам. Это позволит им привязать поставщиков экономически и сохранять свою посредническую роль. Новый формат осуществления продаж вынудит сетевые магазины вкладывать больше средств в реальное производство, чем сегодня. Это обеспечит рост оборота денежных средств.

Также торговые сети (и не только они) могут сделать предметом своих инвестиций и новые стартапы, возникающие на почве кооперации. Механизм работы кооперативов и их взаимодействия с бизнесом следующий.

Организацию монопольного районного потребления целесообразно осуществлять в связке двух кооперативных систем: потребительского кооператива, выполняющего функцию агента потребителей, и территориального общественного самоуправления (ТОС), собственно организующего потребление.

На рис. 1 представлена структура работы ТОС. Слева от центра указаны виды основной работы ТОС, справа - источники доходов со сферой ответственности и направления вложений собственных средств для развития деятельности (она не является коммерческой).

ТОС не собирает средства на реализацию проектов и совершение покупок. Основная функция ТОС - добиться принятия решения гражданами о вложениях в развитие общего имущества и разрешение совместных проблем. Субсидирование данной деятельности обусловлено необходимостью оживления экономической активности граждан и бизнеса, которая, в свою очередь, обеспечит увеличение налогооблагаемой базы.

TOC, так же, как и потребительский кооператив, не является продавцом товаров, оно помогает жителям организовать разрешение проблемных ситуаций (потребительских задач) собственными силами и с привлечением помощи извне. 


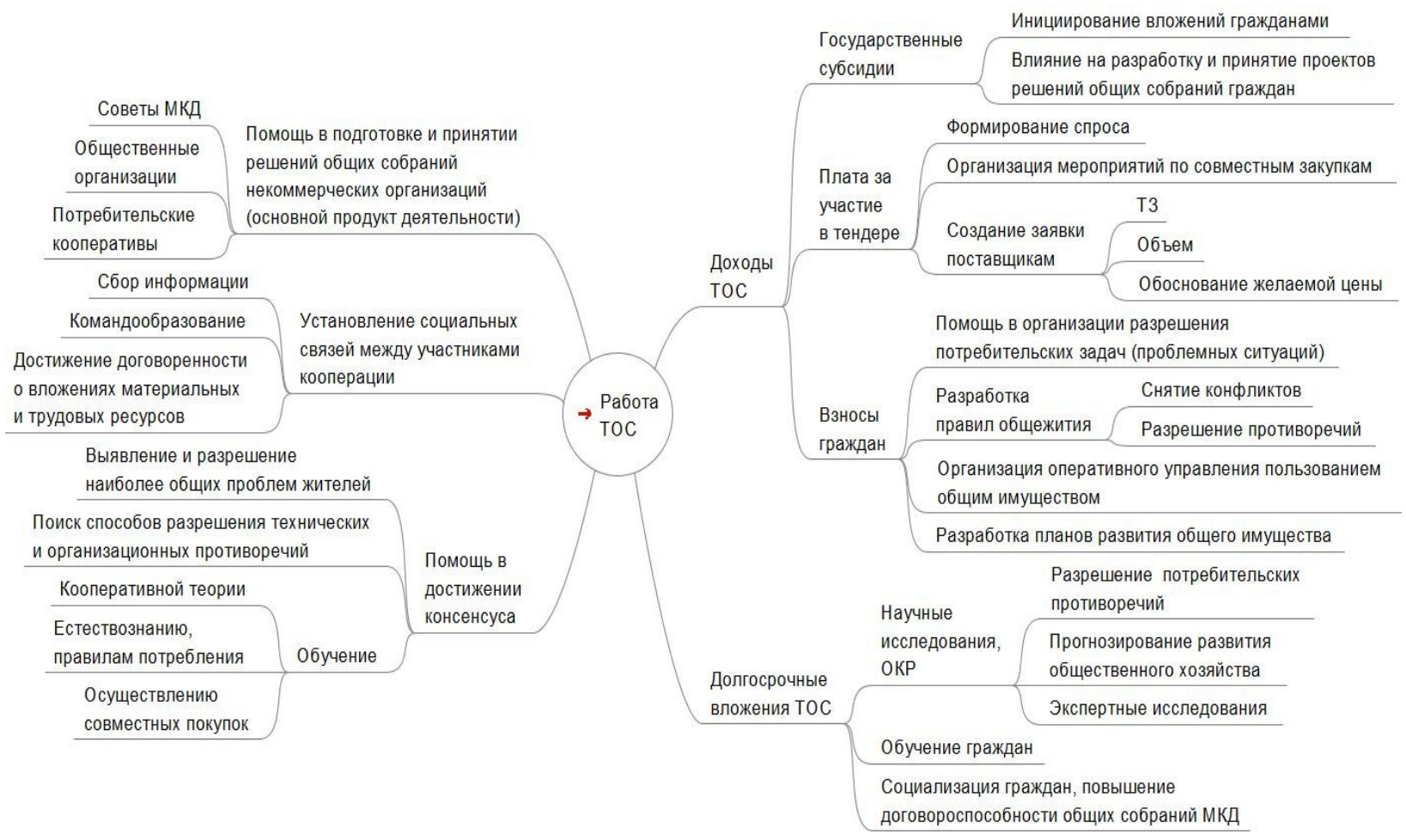

Рис. 1. Организация работы ТОС

Организация потребительского общества микрорайона представлена на рис.2. Его основная функция - сконцентрировать материальные общественные ресурсы для выполнения решений общих собраний участников кооперации, совершение покупок как монополизированного потребителя, обеспечение реализации совместных проектов граждан, в том числе содержание и развитие общей собственности граждан, а также кооператива. Для этих целей кооператив микрорайона должен организовать инфраструктурные вложения и вести хозяйственные отношения с бизнесом. 


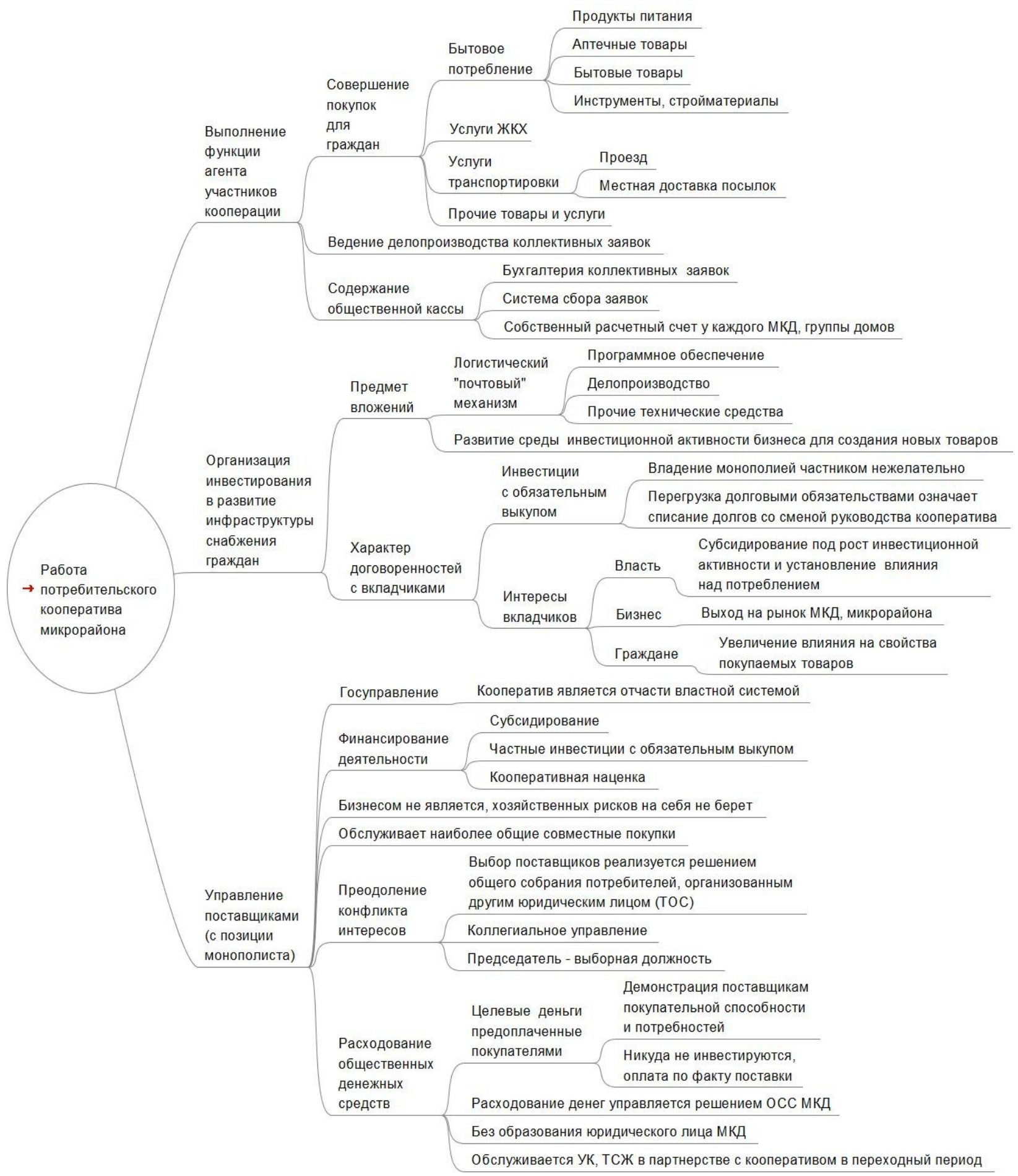

Рис. 2. Потребительский кооператив микрорайона

Общемикрорайонный кооператив обслуживает непосредственное вложение ресурсов в общие интересы местных сообществ. Вкладчиками могут быть любые лица, заинтересованные в осуществлении сбыта, но чтобы собственность при этом оставалась общественной, частные вложения в нее должны осуществляться в виде инвестиций с выкупом совладельцами - участниками кооперации.

Общемикрорайонный кооператив, обладая монопольным положением совместно с ТОС, приобретает власть как над поставщиками, так и над 
потребителями (местными жителями). Получая субсидии, ТОС и кооператив становятся частью системы госуправления. Основной интерес государства в данном случае - добиться вложений ресурсов граждан и бизнеса в решение общих потребительских и государственных задач, что позволит обеспечить увеличение объема имущественных ценностей граждан, товарооборота и за счет этого рост налогооблагаемой базы.

Участие граждан в принятии решений на общих собраниях, организованных TOC, делает возможным качественный учет интересов населения государственными структурами. Это, в свою очередь, обеспечивает готовность участников трехстороннего социального партнерства вкладывать свои средства в общие проекты.

Позитивное сотрудничество бизнеса с потребительской кооперацией может заключаться в частичной оплате в ТОС организации принятия решений общих собраний. Участвуя в формировании спроса, бизнесу легче скорректировать свое предложение.

Это обеспечит дополнительное финансирование научно-технологического развития, так как для приведения граждан к консенсусу и обеспечения тем самым максимального объема сбыта продукции, необходимо разрешать технические и социальные противоречия.

Выверенные групповыми обсуждениями запросы потребителей обеспечивают менее рискованные инвестиции.

Передача государственных функций по защите интересов потребителей потребительской кооперации, представляющей истинные запросы конечных покупателей и осуществляющей приемку товаров по заданию участников кооперации, снизит неэффективное материальное обременение бизнеса и государства и уменьшит коррупционные возможности для чиновников.

\section{Потребительская кооперация и самоуправление}

Местное самоуправление подразумевает разрешение общих местных проблем совместными силами граждан. По сути, это разновидность кооперации, предметом потребления которой являются силы граждан, объединенные для решения общественных задач. Совместное владение многоквартирным домом это тоже потребительская кооперация, только, к сожалению, многими гражданами не признаваемая. Объединение ее в одну систему с кооперативным снабжением продуктами позволит улучшить состояние дел и в сфере ЖКХ.

Радикальное принуждение граждан к принятию кооперативных отношений посредством закрытия продуктовых магазинов вынудит их осваивать кооперативную теорию и кооперативные ценности (являющиеся общечеловеческими: любовь, дружба, взаимопомощь, солидарность, честность и пр.) в противовес буржуазно-либеральным (эгоцентризм, экономическая свобода и пр.). Без такого образования и воспитания кооперация работать эффективно не может, так как она требует принятия солидарной ответственности, а также достижения консенсуса в сообществах. 
Следует отметить, что принятие ответственности за общую судьбу (именно в этом заключается суть предоставления права принимать коллегиальные потребительские решения) затруднительно для современных российских (постсоветских) граждан. Высокий уровень патернализма (перекладывание ответственности на государство) является серьезным консервативным барьером для реализации предлагаемого экономического преобразования. Поэтому целесообразно переводить общество на новые хозяйственные отношения постепенно, выращивать их, оттолкнувшись от (на сегодняшний день немногочисленных) сторонников кооперации, оказывая им всестороннюю поддержку. При этом современная растущая угроза распространения коронавируса требует решительных мер по продвижению новой формы снабжения и торговых отношений.

Помимо консерватизма граждан по отношению к совместному потреблению существует консерватизм в системе управления ЖКХ (жилищно-коммунальным хозяйством) многоквартирных домов, на базе которой предлагается осуществить преобразование системы снабжения граждан.

Для объединения ЖКХ с потребкооперацией по продовольственным закупкам можно воспользоваться юридическими лицами УК и ТСЖ. Однако в обществе сформировался очень высокий уровень недоверия к этим организациям. $\mathrm{K}$ тому же их бухгалтерия не способна быстро справиться с задачей проведения огромного числа заявок граждан с большой номенклатурой товаров.

Так же необходимы поправки в законодательстве для изменения формы соглашения собственников МКД с УК и ТСЖ с договора управления на агентский договор и дообучение сотрудников УК и ТСЖ работе в условиях изменившихся отношений с собственниками МКД. По данным наших исследований самостоятельно переходить на агентский договор с собственниками МКД УК и ТСЖ не готовы.

Поэтому целесообразно начать преобразования отношений между собственниками МКД и поставщиками услуг ЖКХ с создания специализированного общемикрорайонного кооператива, который впоследствии делегирует ТСЖ и УК часть своих агентских функций для более активной работы по удовлетворению интересов жильцов МКД. Кооперативу микрорайона по мере развития целесообразно отвести роль союза кооперативов домов.

Система принятия решений общими собраниями жильцов должна быть независима от исполнителей этих решений (ТСЖ, УК, потребительских кооперативов), так как заказчик и исполнитель выполняют разную работу с полярно противоположными интересами в системе кооперации.

Организацию помощи в принятии решений общих собраний собственников (ОСС) МКД (кооперативов) целесообразно реализовывать через юридическое лицо ТОС. Управление общим имуществом МКД (согласно ЖК РФ) его совладельцы осуществляют посредством решений ОСС МКД. Прочее управление общим кооперативным имуществом (ресурсами) организационно не отличается от управления имуществом ЖКХ. Организация этой деятельности на площадке ТОС совпадает с его целями - реализацией самоуправления граждан, так как 
самоуправление сводится в конечном счете к совместному пользованию какими-то общими ресурсами участников.

Любая деятельность начинается с принятия решений. Сначала принимается решение, потом осуществляется покупка или выполняется работа. Поэтому согласованное с участниками кооперации решение является первичным продуктом деятельности по организации самоуправления ТОС. Далее ТОС передает решение своему агенту - микрорайонному потребительскому кооперативу, а тот, в свою очередь, - ТСЖ и УК. Их функция - вести договорные отношения с поставщиками.

Такой сложный алгоритм осуществления покупки вместо простого посещения магазина упрощается за счет того, что широкомасштабные согласования нет необходимости проводить часто. Текущая работа кооперации это сбор и выполнение штатных заявок своих участников. Согласования и новые совместные решения нужны для преодоления противоречий, которые со временем будут возникать и сообща разрешаться, а также для реализации инфраструктурных и прочих проектов. В настоящее время это происходит без участия граждан, но данные издержки все равно несут потребители в виде более высоких цен и неудовлетворительного качества товаров и услуг.

Большинство противоречий, как и прежде, будет разрешаться без их широкого обсуждения. В процессе подготовки проектов решений общих собраний собственников МКД представители заинтересованных сторон (организаторы кооперации, представители бизнеса и власти) должны приходить к консенсусу. Роль рядовых участников заключается в уточнении проектов решений, в реализации обратной связи производителя с потребителем и власти с гражданами.

Достижение консенсуса между заинтересованными сторонами обеспечивает снижение числа возможных проблем в процессе и после реализации личных и государственных потребительских проектов. Таким образом будет достигаться повышение качества потребления при меньших материальных затратах.

Чтобы граждане вкладывали материальные средства и трудовое участие в достижение консенсуса и обеспечивали условия для инвестиционной активности бизнеса, власть должна выступать на стороне граждан, обеспечивая целевое расходование собранных общественных средств.

Сегодня в УК и ТСЖ осуществляется принудительный сбор денег на обслуживание общего имущества МКД (согласно Жилищного кодекса РФ). Поэтому УК и ТСЖ агентами жильцов не являются, воле собственников без содействия власти не подчиняются. Также они не заинтересованы тратить средства на достижение согласия среди собственников МКД, так как совладельцы сопротивляются дополнительным расходам на содержание своего МКД, не имея возможности влиять на расходование собираемых средств.

Переход от договора управления с УК и ТСЖ в пользу агентского договора с ними (для этого необходимо влияние власти) изменит характер содержания многоквартирных домов и резко расширит возможности для прочей потребительской кооперации. 
Влияние органов власти на ведение хозяйства УК и ТСЖ целесообразно снизить, направив его акцентирование на работу ТОС. Управление ЖКХ может осуществляться органами власти путем воздействия на процесс принятия решений ОСС МКД, опираясь на правила определения последовательности выполнения работ по содержанию и ремонту дома, а также посредством субсидирования кооперации в рамках государственных программ. Таким образом, УК и ТСЖ преобразуются в агента МКД, административно подчиненного ТОС через влияние потребителей и государственной власти [20].

Роль государства по содержанию общего имущества меняется. Сегодня развитие общественной инфраструктуры осуществляется посредством фискальной политики (например, принудительного платежа за содержание жилья). В экономике нового типа данная функция во многом упраздняется. Вместо принудительного сбора денег со всех граждан роль власти заключается в оказании давления на «безбилетников» [21] (лиц, уклоняющихся от вложений в общее, но пользующихся им). Принятие решения о вложении в совместное имущество осуществляется общим собранием его совладельцев.

Увеличение вложений в коллективный ресурс должно достигаться влиянием на ведение совместного хозяйства через субсидии и участие в принятии решений общими собраниями членов кооперации. Далее на почве возникшей инвестиционной активности осуществляется сбор налогов на государственные нужды. Получив бюджетные средства на субсидии общественных организаций, чиновники на местах должны нести ответственность перед вышестоящими руководителями за рост инвестиционной активности со стороны граждан и бизнеса.

Чтобы существенно сэкономить время и быстрее закрыть магазины для посещения розничных покупателей в условиях карантинных изоляционных мер, целесообразно кооператив микрорайона оснастить быстро доступным программным обеспечением, автоматизирующим процесс работы с заявками на уровне интернет-магазина. При этом кооператив магазином не является и не должен им быть.

Принятие на начальной стадии бухгалтерских программ и сайта Интернетмагазина позволит сэкономить время на освоение нового ресурса всеми пользователями, уже имеющими навыки работы с подобной системой. Однако далее система отношений с потребителями должна планомерно превращаться в реальную кооперацию с развитием в ней демократии.

По существу, речь идет о формировании реального местного самоуправления, управляемого властью посредством влияния на принимаемые в TOC общими собраниями решения при помощи субсидий и законодательных актов [22]. Государство сможет осуществлять контроль и планирование снабжения, а также влиять на технологическое развитие, создавая дополнительные привлекательные условия для инвестиций со стороны бизнеса. Это (особенно сегодня) позволит стабилизировать разбалансировавшуюся карантинными ограничениями экономику, взять под управляемый мягкими методами контроль подавляющее большинство сфер жизни общества, в том числе 
данная система позволит повысить эффективность карантинного поведения людей с минимальной необходимостью применять усиление полицейских мер.

\section{Городской транспорт и вирусоуязвимость}

Сформированная система демократичного управления общественным потреблением позволит реформировать общественный транспорт. В условиях самоизоляции целесообразно сделать так, чтобы в «автобусах» могли одновременно перемещаться только люди из одной организации или проживающие по соседству. Если они подчиняются ее руководству, то это облегчает реализацию карантинного поведения граждан в общественном транспорте.

Через жилищную кооперацию граждане смогут решить свои бытовые транспортные задачи, предприятия также смогут нанимать «автобусы» для своих сотрудников, чтобы доставлять их на работу и возвращать после нее домой. Это означает возможность изменения принципов организации городского транспорта. Вместо маршрутных автобусов будут преобладать заказные. Во время карантинных ограничений в них можно реализовать эффективные меры, направленные против заражения пассажиров, под контролем заказчиков поездки.

Современные электронные мультиагентные системы [22-23], проявившие себя эффективно в организации такси, способны оптимизировать пользование имеющимися транспортными средствами. С их помощью можно оптимизировать транспортные расходы: прокладывать маршруты с пересадками, согласовывать пути перемещения по дорогам, синхронизировать движение машин и т. д. Трамваи, троллейбусы и метро могут утратить свое прежнее назначение.

Эта система организации транспорта способна облегчить дальнейшее развитие движения машин по дорогам посредством роботизации, усовершенствования городской логистики со снижением числа транспортных задач для потребителей. Она же обеспечит сокращение, и в дальнейшем ликвидацию, пробок на дорогах, а также уменьшит нагрузку на дорожное полотно. Изменится сама постановка задачи для производителей машин, автобусов и прочего транспорта, что даст новый импульс для инвестиционной активности в эту отрасль.

Следует акцентировать внимание на том, что чем меньше потребности в перемещении людей, тем это удобнее гражданам, и тем меньше распространение инфекции. Локализация работы (временной и постоянной) неподалеку от дома, внутри микрорайонного сообщества поможет решать и задачу занятости, и ограничения распространения инфекции.

Снижение потребления машин сокращает доходы автотранспортной и сырьевой отраслей. Принятие политики власти, направленной в первую очередь на удовлетворение интересов граждан (потребителей), а не бизнеса, облегчит преодоление консерватизма производителей товаров.

\section{ЗАКЛЮЧЕНИЕ}


Описанная в статье коллективизация потребления позволит обеспечить условия для формирования нового технологического уклада жизни на базе новой инвестиционной активности, обслуживающей коллективный заказ. Это позволит создать конкурентоспособную экономику иного типа.

Для реализации предлагаемых нововведений необходимо:

- выявить противоречия с предлагаемой системой ведения общественного хозяйства в законодательстве и внести необходимые изменения в пользу формирования развитой потребительской кооперации в связке с местным самоуправлением;

- создать региональные потребительские кооперативы на уровне микрорайонов;

- усовершенствовать уставы ТОС, ориентируясь на работу по организации принятия решений общими собраниями местных сообществ как на основную задачу самоуправления;

- заключить новые договоры между сообществами совладельцев МКД и ТОС «О помощи в принятии решений общими собраниями совладельцев МКД»;

- субсидировать принятие решений общими собраниями многоквартирных домов через ТОС;

- принять законодательно новый модельный договор с УК с переходом на форму агентского соглашения;

- пропагандировать кооперативное движение с кооперативными ценностями.

Уже сегодня окажется возможным закрыть магазины для посещения без потери рабочих мест их сотрудниками, существенных потерь сбыта и снижения инвестиционной активности, а также преобразовать общественный транспорт в «коллективное такси» с базовым пользователем потребительским кооперативом.

Основой для коллективизации потребления предлагается сделать сообщества совладельцев многоквартирных домов. Это позволит гражданам экономить ресурсы благодаря близкому проживанию. К тому же зачатки кооперации здесь уже существуют в виде совладения МКД.

Преобразование управляющих компаний и ТСЖ в агентов совладельцев жилья, а также создание отдельной системы принятия коллективных решений на базе ТОС обеспечит необходимые условия для увеличения вложений собственников домов в решение общих задач. Структура, обслуживающая потребление МКД, может использоваться и для любого другого совместного потребления, в первую очередь, продуктов питания и услуг транспорта. В ней также заложен потенциал для преобразования системы потребления медицинских услуг.

Набор эпидемиологических угроз не ограничивается одним коронавирусом. Поэтому целесообразно не дожидаться худшего сценария развития событий и принимать эффективные меры предотвращения распространения инфекций и формирования новой экономики, примирившись с достаточно непривычным для современного человека коллективным стилем жизни, который, при правильной его организации, сулит гражданам гораздо более благополучную жизнь, чем сегодня. 


\section{ЛИТЕРАТУРА}

1. Воронцов С.А. О соотношении прав и свобод человека с уровнем безопасности личности, общества, государства в период пандемии // Наука и образование: хозяйство и экономика; предпринимательство; право и управление. 2020. № 5 (120). С. 50-53.

2. Гулакова В. Ю., Касторнов Н. С. Об организационно-правовых мерах борьбы с пандемией в России // Базис. 2020. № 1 (7). С. 26-29.

3. Долматова И. А. Зайцева Т. Н. Обслуживание потребителей в условиях карантина по короновирусу. // Проблемы конкурентоспособности потребительских товаров и продуктов питания: сборник научных статей 2-й международной научно-практической конференции. Курск, 2020. С. 144-147.

4. Толстых А. И. Актуальные тенденции в сфере российского ритейла // Научный электронный журнал меридиан. 2020. № 6 (40). С. 60-62.

5. Хасуев А. Э. Социальная изоляция и самоизоляция человека: социальнофилософский анализ // Экономические и гуманитарные исследования регионов. 2020. № 2. С. 122-128.

6. Федосенко Е. А. Жизнь после карантина: психология смыслов и коронавирус COVID-19 // психологические проблемы смысла жизни и AKME: Материалы XXV Международного симпозиума. Москва, 15-16 апреля. 2020. С. 34-47.

7. Шматова Ю.Е. Влияние COVID-19 на психическое здоровье населения (как показатель человеческого потенциала): опыт зарубежных исследований // Проблемы развития территории. 2020. № 4 (108). С. 88-108. DOI: 10.15838/ptd.2020.4.108.6

8. Морозов С. А. Каким будет ущерб от вспышки коронавируса для глобальной экономики? // Научный электронный журнал меридиан. 2020. № 8 (42) C. $456-458$.

9. Молдован А. А., Секретнова А. О. Влияние коронавируса на экономику России // Аллея науки. 2020. № 4 (43) С. 355-358.

10. Шулепов Е.Б., Задумкин К.А., Щербакова А.А. Роль социального партнерства в развитии городов и механизмы его формирования // Проблемы развития территории. 2020. № 4 (108). C. 20-36. DOI: 10.15838/ptd.2020.4.108.2

11. Ивашкин М. В., Колесников А. В. Совместная покупка как экономическая категория и рынок совместных покупок в информационном обществе // Вестник Тихоокеанского государственного университета. 2019. № 2 (53). C. 55-62.

12. Костина С. Е. Правовая природа совместных покупок // Вестник Саратовской государственной юридической академии. 2015. № 4 (05). С. 44-47.

13. Норин А. В. Договор с управляющей организацией как договор подчинения. URL: https://cyberleninka.ru/article/n/dogovor-s-upravlyayuscheyorganizatsiey-kak-dogovor-podchineniya (дата обращения: 10.10.2020).

14. Seiler S. The impact of search costs on consumer behavior: A dynamic approach // Quantitative Marketing and Economics. 2013. № 11 (2). P. 155-203. 
15. Моисеева Т. В. Проблемы интерсубъективного управления инновационным развитием социотехнических объектов // Вестник СамГТУ. Серия «Технические науки». 2017. № 3 (55). С. 16-31.

16. Талер Р. Новая поведенческая экономика. Почему люди нарушают правила традиционной экономики и как на этом заработать. // Misbehaving: The Making of Behavioral Economics. - Эксмо, 2017. - 368 с.

17. Vittikh V. A. Introduction to the theory of intersubjective management // Group Decision and Negotiation. 2015. № 24 (1). P. 67-95.

18. Моисеева Т. В., Поляева Н. Ю. Моделирование проблемной ситуации в теории интерсубъективного управления // Вестник Дагестанского государственного технического университета. Технические науки. 2018. № 45 (1). С. $160-171$.

19. Мятишкин Ю. В. Средства достижения консенсуса в широких группах людей, объединенных общей проблемной ситуацией // Проблемы управления и моделирования в сложных системах : труды XIX Междунар. конф. Самара: Изд-во ООО «Офорт», 2017. С. $338-345$.

20. Мятишкин Ю.В. Формирование системы управляемого самоуправления в многоквартирных домах // Модернизация российского общества и образования: новые экономические ориентиры, стратегии управления, вопросы правоприменения и подготовки кадров: мат-лы XXI нац. научн. конф. (с межд. участием). Таганрогский ин-т управления и экономики, 2020. С. 349-351

21. Остром Э. Управление общим. Эволюция институций коллективного действия; пер. с англ. Т. Монтян. Киев, 2013. 400 с.

22. Виттих В. А., Моисеева Т. В., Скобелев П. О. Принятие решений на основе консенсуса с применением мультиагентных технологий // Онтология проектирования. 2013. № 2. С. 20-25.

23. Скобелев П. О., Майоров И. В. Мультиагентные технологии в интеллектуальных системах управления ресурсами в реальном времени // Морские информационно-управляющие системы. 2015. № 1 (7). С. 24-39.

\section{THE REFORM OF REGIONAL SUPPLY: COLLECTIVIZATION OF CONSUMPTION}

The problem of the spread of coronavirus infection makes us to take a fresh look at the organization of the economy. How to maintain the viability of the national economy, when personal contacts between people are sharply reduced, in order to avoid transmission of the disease in a pandemic? How to ensure new investment activity? How to improve the discipline of withstanding the epidemic?

If an organization has hierarchical system of management, it is possible to force their members to follow the rules, but outside the workplaces it is difficult to influence people without the use of police measures. There are constantly accumulations of random people who don't fulfil sanitary rules in shops and public transport, giving rise to an uncontrolled spread of infection. 
In this regard, it is proposed to create a consumption management system, limiting store retail trade and developing consumer cooperation. The proposed changes are based on a new mechanism of relations between citizens, authorities and non-profit organizations, which represents the more developed system of their social partnership than is available today.

As a result of the transformation of the supply system for local residents, regional authorities will be able to influence the nature of consumption through participation in setting tasks for suppliers together with citizens. Thus, based on the interests of the population, it will be able to better determine the direction of business investment in the development of production of goods and services.

Compliance with local rules of consumption and social behavior, developed by self-government bodies and adopted by citizens by a decision of the general meeting, will improve the quality of consumption, reduce the need for police measures to maintain law and order (including implementation of quarantine measures), and create additional investment activity through the system of group formation of demand for new goods and changes in the economic status of retail.

Quarantine, self-isolation, consumer cooperation, self-government, social partnership, joint purchases, retail trade, urban transport. 